\title{
Vulkansk aktivitet på Jorden - nyt fra de sidste seks måneder
}

Af geolog Susanne Plesner, GeologiskNyt

De seneste 6 måneder har der været vulkansk aktivitet over hele Jorden, men særligt interessant har det været at følge Kilauea på Hawaii, hvor et kollaps af relativt nydannet landmasse i længere tid var undervejs og endelig fandt sted november 2005.

Igen har vi det meste af vores klode repræsenteret ved vulkansk aktivitet. I det første halvår af 2005 lå det meget stille i Afrika, men denne verdensdel er kommet med igen med hele tre vulkaner repræsenteret. Indonesien er ikke helt så talrigt repræsenteret denne gang, til gengæld er aktiviteten forhøjeti Mellemamerika.

Hen over sommeren har Hawaii været nævnt nogle gange i verdenspressen, da et større område af relativt nydannet landmasse truede med at styrte i havet. Det er nu sket og vil blive forklaret nedenfor som det specifikt udvalgt område denne gang.

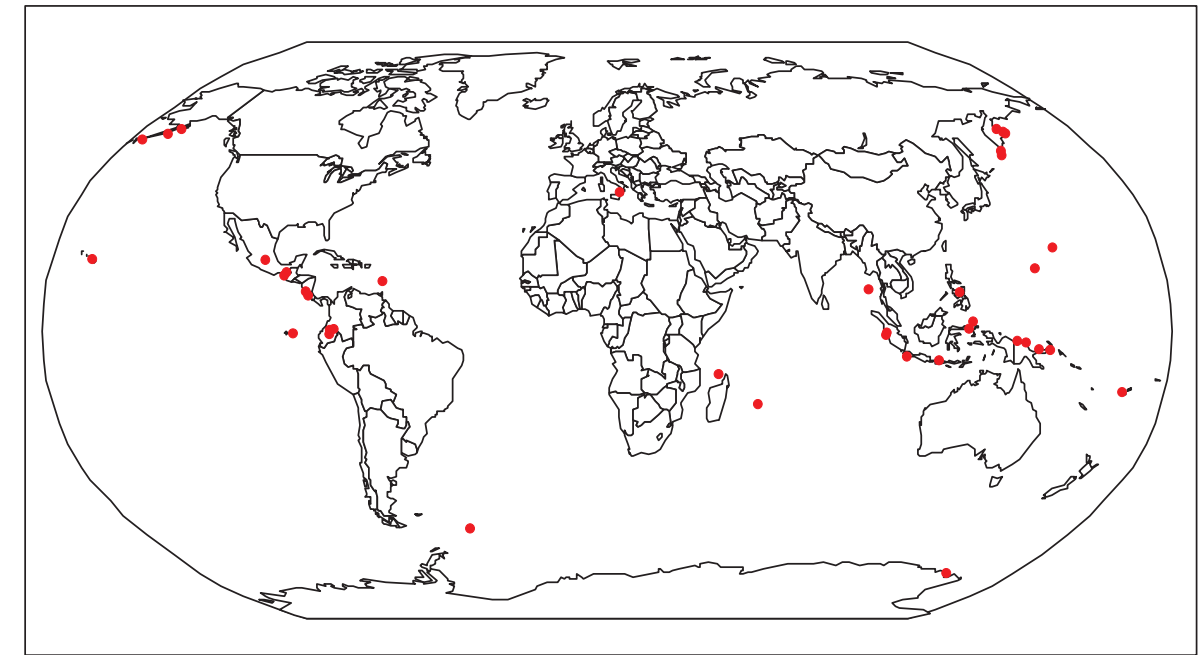

Verdenskort, der med røde fyldte cirkler viser fordelingen af den vulkanske aktivitet de seneste seks måneder. (Grafik: Forfatteren)

Lava skaber nye landområder

Kilauea på Hawaii har været kontinuerligt i udbrud siden januar 1983. Hawaii er et af de få steder i på Jorden, hvor man kan komme helt tæt på den aktive lava uden den store fare for liv og lemmer, hvis man blot bruger

\section{Vulkansk aktivitet de sidste 6 måneder}

Europa

Stromboli, Italien

\section{Nordlige Stillehavsregion}

Kilauea, Hawaii, USA

Cleveland, Aleutian Islands, USA

Anathan, Mariana Øerne (USA)

Suwanose-Jima, Ryukyu Øerne, Japan

Sakura-Jima, Kyushu, Japan

Mayon, Filippinerne

Dukono, Halmahera, Indonesien

Karangetang, Indonesien

Sydlige Stillehavsregion

Talang, Indonesien

Marapi, Sumatra, Indonesien

Papandayan, Java, Indonesien

Ijen, Java, Indonesien

Bagana, Papua Ny Guinea

Gabuna Group, Papua Ny Guinea

Langila, Papua Ny Guinea

Rabaul, Papua Ny Guinea

Ulawun, Papua Ny Guinea
Manam, Papua Ny Guinea

Pago, Papua Ny Guinea

Erebus, Ross Island, Antarktis

Montagu Island, Sandwish Øerne

Aoba, Vanuatu

Afrika

Ol Doinyo Lengai, Tanzania

Dabbahu, Etiopien

Nyiragongo, Den Demokratiske Republik

Congo

\section{Nordamerika \\ Veniaminof, Alaska \\ Katmai, Alaska, USA}

Mellemamerika, Mexico og Vestindien Arenal, Costa Rica

Colima, Mexico

Popocatépetl, Mexico

Fuego, Guatemala

Santa María, Guatemala

Pacaya, Guatamala
Soufriere Hills, Montserrat

Concepción, Nicaragua

San Cristóbal, Nicaragua

Santa Ana, El Salvador

Sydamerika

Sierra Negra, Galapagos

Tungurahau, Ecuador

Reventador, Ecuador

Sangay, Ecuador

Galeras, Columbia

Rusland

Ebeko, Kurillerne

Bezimianny, Kamchatka

Karymsky, Kamchatka

Kliuchevskoi, Kamchatka

Shiveluch, Kamchatka

Indiske ocean

Piton de la Fournaise, Réunion

Karthala, Comoro øerne

Barren Island, Indien 


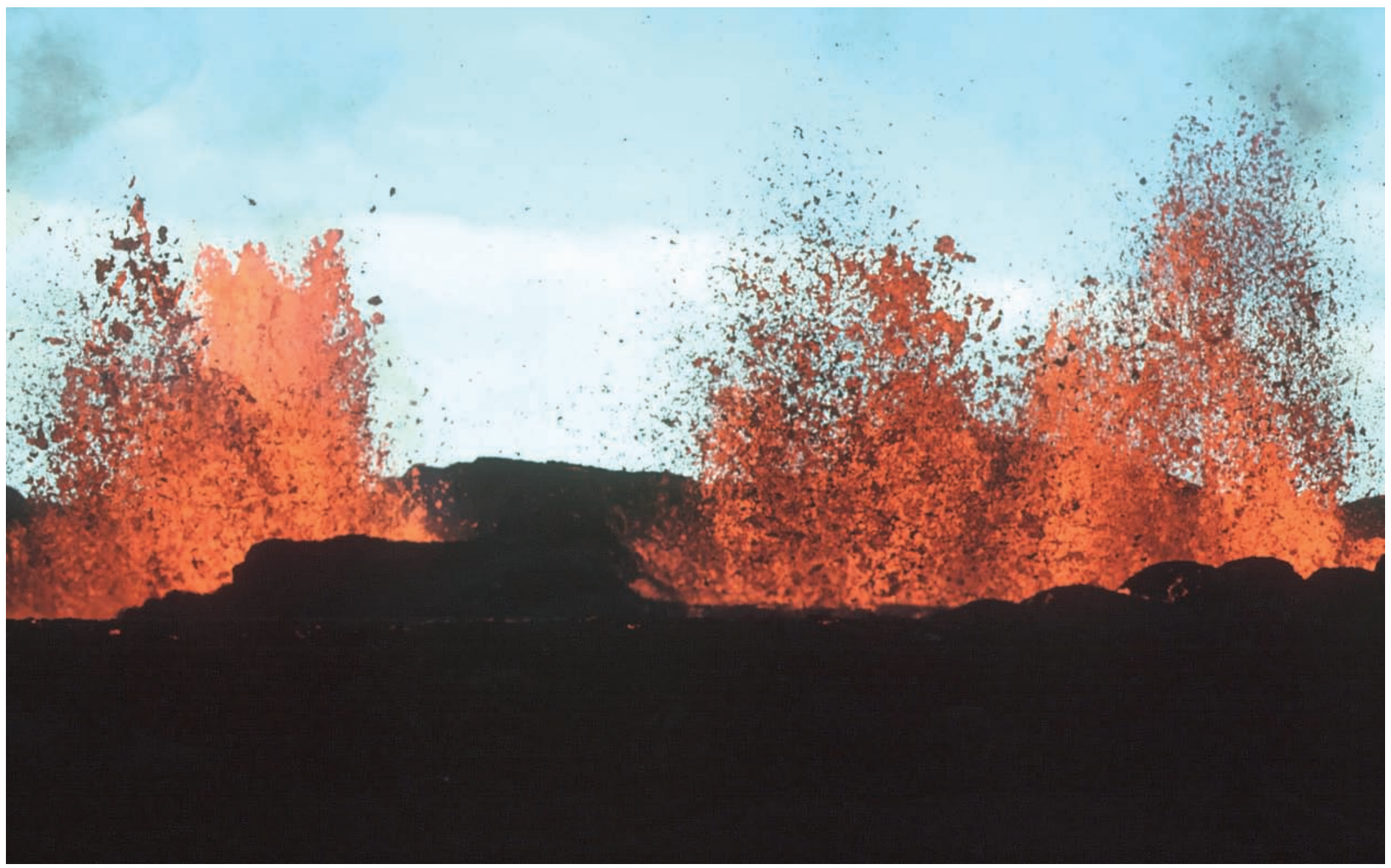

Vulkansk aktivitet på jorden, billedetekst: Et sprcekkeudbrud var begyndt den 18 oktober 1980 nord for Leirhnjúkur i Krafla, Island. Efter nogle få dage, var aktiviteten koncentreret til et krater. (Foto: Halldór Ólafsson den 20 oktober)

sin sunde fornuft, og det er der selvfølgelig mange, der benytter sig af. Der er som regel overfladestrømme at se et eller andet sted, og ofte kan man også se lavaen løbe ud i havet enten direkte via en overfladestrøm, eller også løber den via lavatunneler ud i havet.

Lavaen skaber store områder med nyt land, og selvom det oppefra ser stabilt ud, er det ikke nødvendigvis tilfældet, da det pludseligt kan blive ustabilt og styrte i havet.

\section{Kollaps af nye landmasser}

Det var, hvad der skete for nylig. I juli 2005 afspærrede personalet i Hawaii Volcanoes National Park (hvor den vulkanske aktivitet i øjeblikket er koncentreret) et større område i nærheden af kysten. Flere gange kollapsede lavabrinken, og mindre områder styrtede i havet.

Først 28. november 2005 kom det store kollaps, som havde været ventet i næsten et halvt år. Næsten 14 hektar af relativt nyt land samt yderligere 4 hektar af den bagvedliggende landmasse skred i havet $\mathrm{i}$ løbet af få timer og endte med at blive det største af denne type kollaps i de 23 år, det seneste udbrud har varet.

Faren består ikke blot i, at jorden kan forsvinde under fødderne på en. Selvom man er et pænt stykke fra kystlinien, kan nedstyrtet materiale udløse en eksplosion, hvor lavablokke kan blive kastet et godt stykke ind på land. Det er ikke unormalt at finde blokke på 70 - 80 centimeter i dia- meter optil 10 meter inde på land.

Sikkerhedszonen, hvis man skal undgå materiale, der kan være dødbringende, er ca.100 meter. Kommer man for tæt på, kan man ligeledes blive ramt af skoldhedt saltvand eller endda flydende lava.
Relevante links:

http://www.volcano.si.edu/reports/usgs/ index.cfm?content $=$ archive

http://hvo.wr.usgs.gov/

http://volcano.und.nodak.edu/

http://www.honoluluadvertiser.com/

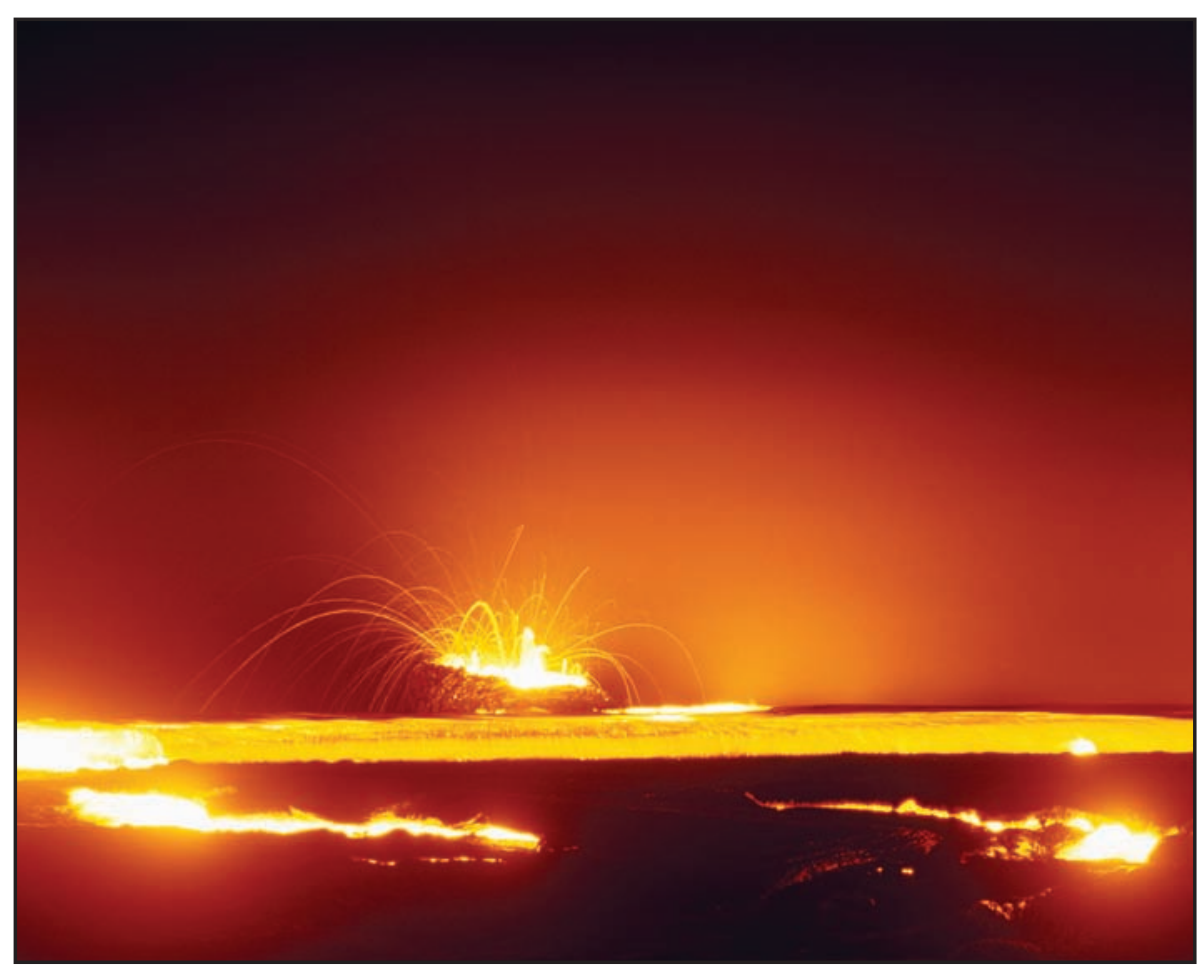

Kilauea i udbrud i december 2003. (Foto: Tom Pfeiffer) 